\title{
Unified MPPT Control Strategy for Z-Source Inverter Based Photovoltaic Power Conversion Systems
}

\author{
Sengodan Thangaprakash ${ }^{\dagger}$ \\ ${ }^{\dagger}$ School of Electrical Systems Engineering, University Malaysia Perlis, Kuala Perlis, Malaysia
}

\begin{abstract}
Z-source inverters (ZSI) are used to realize both DC voltage boost and DC-AC inversion in single stage with a reduced number of power switching devices. A traditional MPPT control algorithm provides a shoot-through interval which should be inserted in the switching waveforms of the inverter to output the maximum power to the Z-network. At this instant, the voltage across the $\mathrm{Z}$-source capacitor is equal to the output voltage of a PV array at the maximum power point (MPP). The control of the Z-source capacitor voltage beyond the MPP voltage of a PV array is not facilitated in traditional MPPT algorithms. This paper presents a unified MPPT control algorithm to simultaneously achieve MPPT as well as Z-source capacitor voltage control. Development and implementation of the proposed algorithm and a comparison with traditional results are discussed. The effectiveness of the proposed unified MPPT control strategy is implemented in Matlab/Simulink software and verified by experimental results.
\end{abstract}

Key Words: Capacitor voltage control, Maximum power point tracking, Photovoltaic array, Pulse width modulation, Z-source inverter

\section{INTRODUCTION}

Concerns for developing alternative energy systems have been increasing continuously. Among them, solar energy systems are one of the more important solutions because they produce electric power without inducing environmental pollution. Many studies on maximum power point tracking (MPPT) algorithms for the development of low cost, high efficiency solar energy systems have been completed [1][8]. Photovoltaic (PV) power conversion systems (PCS) for converting solar energy into electricity are in general costly. As a result, they are a viable method for generating electricity only if they can produce the maximum possible output under all weather conditions. Among the various types of PCSs, two stage converters have been used to boost PV voltage to a desired level and to convert $\mathrm{DC}$ into $\mathrm{AC}$ for controlling the AC loads. The number of switching components, the total volume of the system and the overall cost of the system are increased while adapting a two stage converter based PCS. A Z-source inverter (ZSI) is proposed to overcome the disadvantages of traditional voltage and current source inverters [9]. The block diagram of a ZSI with a unique impedance network which provides single stage DC to AC

Manuscript received Nov. 1, 2010; revised Nov. 9, 2011

Recommended for publication by Associate Editor Seung-Ho Song.

$\dagger$ Corresponding Author: thangaprakash@unimap.edu.my

Tel: +60163884059 , University Malaysia Perlis

School of Electrical Systems Engineering, University Malaysia Perlis,

Malaysia power conversion is shown in Fig. 1. ZSI based PCSs are the center of a lot of attention for researchers since they offer both DC boost and DC-AC inversion in a single stage. Due to their unique features and advantages as outlined in the literature [9]-[14], they are finding wide spread applications. A ZSI is highly suitable for driving induction motors under supply voltage sags/fluctuations and provides enhanced ride-through capability throughout operation [14]-[16]. The suitability and operation of a ZSI for various applications have been studied by various researchers [17]-[23]. Many control algorithms have been proposed to control the voltage across the inverter's DC terminals (DC link voltage) as well as the AC output voltage [24]-[30]. The operating principle of a ZSI based PCS for PV systems and their advantages over the traditional two stage converters has been discussed in [17]. A simple power feedback method is used to achieve MPPT in [17]. The same study has been extended to grid connected PV systems in [31]. A simple control method for a two-stage utility gridconnected PV-PCS is proposed in [32]. This approach enables maximum power point tracking (MPPT) control with poststage inverter current information instead of calculating the solar array power, which significantly simplifies the controller and the sensor. A power conversion circuit for a grid-connected PV system using a Quasi-ZSI was suggested and analyzed in [33]. A modified perturbation and observation (P\&O) method was used for the MPPT control.

In all of these methods, the output of the MPPT controller is the reference signal for generating a shoot-through state to 


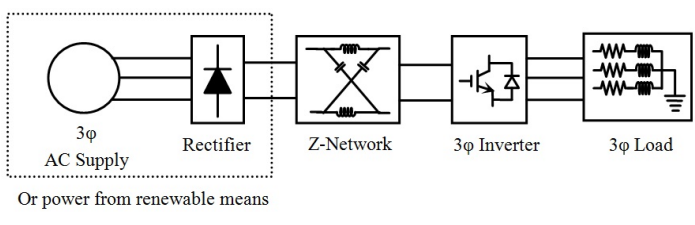

Fig. 1. Block diagram of Z-source inverter based PCS.

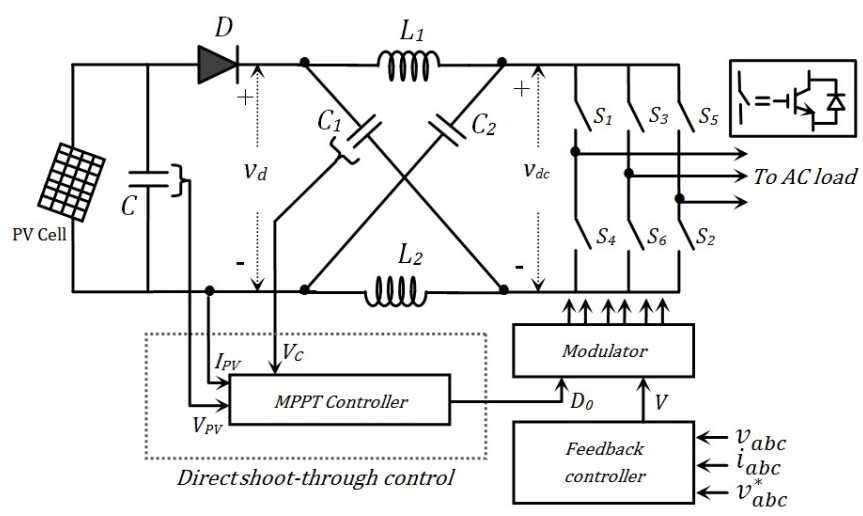

Fig. 2. Z-source inverter based photovoltaic power conversion system.

track the PV voltage at the maximum power point (MPP). This voltage is the reference voltage for the Z-source capacitor and the Z-source capacitor voltage is boosted to the PV voltage at the MPP $\left(V_{P V} *\right)$. The voltage across the Z-source capacitor $\left(V_{C}\right)$ is equal to the photovoltaic array voltage at the MPP $\left(V_{P V}{ }^{*}\right)$. If there is any variation in the load power demand, the DC link voltage has to be adjusted accordingly. To satisfy the above situation, the Z-source capacitor voltage must be increased/decreased according to the requirement of the load. Since a MPPT algorithm generates a shoot-through period to extract the maximum power point voltage from the solar cell, this shoot-through period is unable to boost the capacitor voltage further than the desired level. This paper presents a capacitor voltage control (CVC) along with a modified MPPT algorithm to simultaneously achieve MPPT as well as capacitor voltage control.

\section{Z-SOURCE INVERTER BASED PV-PCS}

A ZSI can be used to realize both DC voltage boost and DC-AC inversion in single stage with additional features that cannot be accomplished with the traditional PV-PCS. The power circuit of a PV based three phase ZSI with the traditional direct shoot-through control structure is shown in Fig. 2. An impedance network containing two equal (split) inductors in series and diagonally connected to two equal (split) capacitors, outputs DC voltage (DC link voltage) to a three phase inverter bridge which is comprised of six power IGBT's with anti-parallel diodes. The Z-network facilitates the shoot-through states so that they are utilized more advantageously without any harmful effects to the inverter operation. A ZSI has minimum kVA requirement when compared with traditional two stage PV power conversion systems [17]. The PV model is developed using the basic circuit equations of the solar cells including the effects of solar irradiation and temperature changes [34]. The traditional MPPT control algorithm provides a shoot-through interval which should be

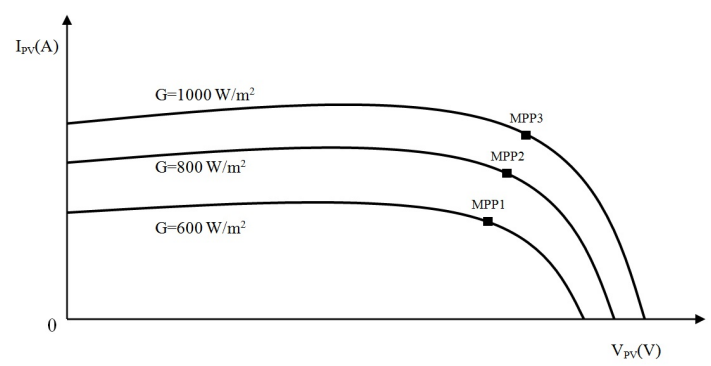

(a)

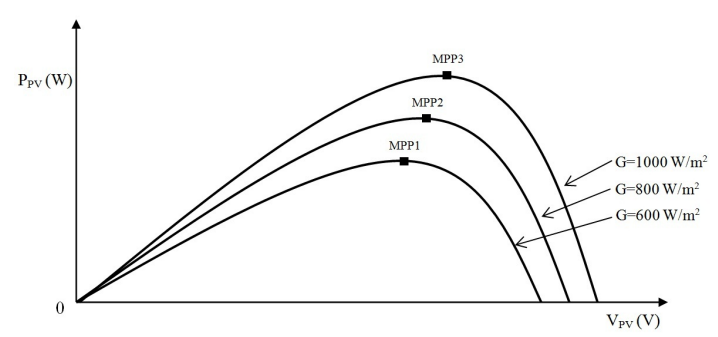

(b)

Fig. 3. I-V and P-V characteristics of PV array.

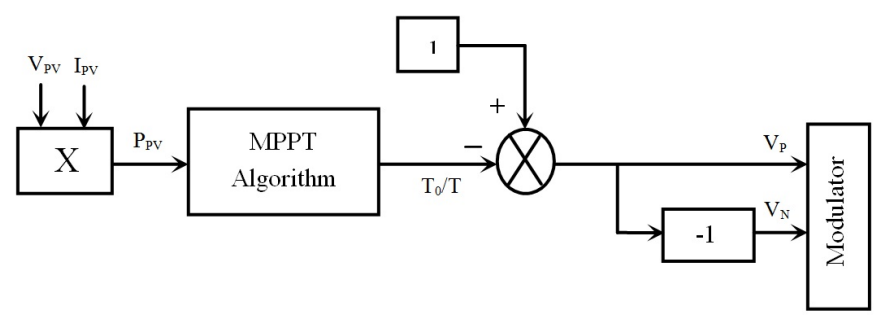

(a)

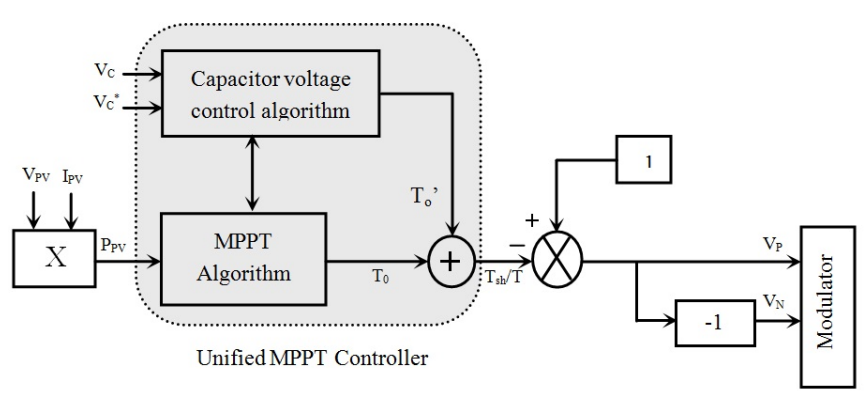

(b)

Fig. 4. ZSI PV-PCS control block diagram. (a) Traditional controller. (b) Proposed unified controller.

inserted in the switching waveforms of the inverter to output maximum amount of power to the Z-network. At this instant, the voltage across the $\mathrm{Z}$-source capacitor, $\mathrm{V}_{C}$ is equal to the output voltage of the PV array $\left(V_{P V}\right)$. Now the AC output voltage of the inverter is controlled as dictated by the AC voltage feedback control loop. A ZSI has three operating modes, namely an active (non shoot-through) mode, a shootthrough mode and a traditional zero mode.

From the symmetry of the Z-source network the following is obtained:

$$
V_{C 1}=V_{C 2}=V_{C} ; v_{L 1}=v_{L 2}=v_{L}
$$

where $V_{C}$ is voltage across the Z-source capacitor, and $v_{L}$ is 


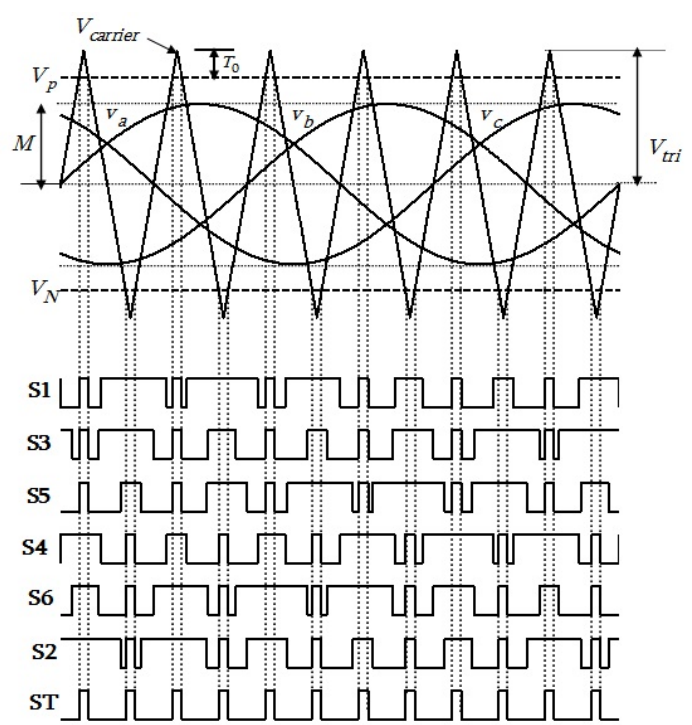

Fig. 5. Simple boost control using $\mathrm{P} \& \mathrm{O}$ method.

voltage across the inductor.

During one of the six traditional active states, the inverter bridge acts as a traditional VSI, thus acting as a current source as viewed from the Z-source circuit. Because of the symmetrical configuration of the circuit, both of the equal inductors have identical current values. The diode $D$, shown in the power circuit is forward biased in this case. The voltage across the Z-network in this case can be written as follows:

$$
\begin{gathered}
v_{L}=V_{P V}-V_{C} ; v_{d c}=V_{P V} \\
\hat{v}_{d c}=V_{C}-v_{L}=2 V_{C}-V_{P V}
\end{gathered}
$$

where $V_{P V}$ is the output voltage of the PV array, $v_{d c}$ is the DC link voltage and $\hat{v}_{d c}$ is the peak DC link voltage of the inverter.

The inverter bridge is under the shoot-through state for an interval, $T_{0}$, during a sampling period, $T$. The diode $(D)$, shown in the power circuit in Fig. 2, will be reverse biased in this case and the PV source is separated from the Z-network. The Z-source capacitors charge the inductors. This mode is inserted in the traditional zero periods $\left(T_{z}\right)$ in every switching cycle $(T)$. The shoot-through interval or its duty cycle is determined based on the voltage boost needed. It should be noted that, the shoot-through interval is only a fraction of the switching cycle. As a result, it needs a relatively small capacitor to suppress the voltage [9]. The voltage across the impedance elements can now be related as:

$$
v_{L}=V_{C} ; V_{P V}=2 V_{C} ; v_{d c}=0 .
$$

During one of the two traditional zero states, (i.e. shorting through either the upper or lower three switches) the inverter bridge is acting as an open circuit as viewed from the Znetwork.

The peak DC link voltage across the inverter bridge, expressed in equation (2), can be written as:

$$
\hat{v}_{d c}=V_{C}-v_{L}=2 V_{C}-V_{P V}=\frac{1}{1-2 D_{0}} V_{P V}=B V_{P V}
$$

where $B$ is the boost factor and $D_{0}$ can be referred to as the shoot-through duty ratio and is equal to $\left(\frac{T_{0}}{T}\right)$.

The boost factor $(B)$ can be related to the shoot-through duty ratio as follows:

$$
B=\frac{1}{1-2\left(\frac{T_{0}}{T}\right)}=\frac{1}{1-2 D_{0}} .
$$

During the non-boost mode of operation and in the steady state, the average voltage across the Z-source capacitor is equal to the voltage across the DC-link of the ZSI. This can be written as follows:

$V_{c 1}=V_{c 2}=V c=\frac{1-\left(\frac{T_{0}}{T}\right)}{1-2\left(\frac{T_{0}}{T}\right)} V_{P V}=\frac{1-D_{0}}{1-2 D_{0}} V_{P V}=\frac{B+1}{2} V_{P V}=V_{P V}^{*}$

where $V_{P V}^{*}$ is the MPP voltage of the PV panel.

The voltage stress $\left(V_{s}\right)$ across the power IGBT's is equal to the peak DC link voltage. In addition to the above equations, it should be noted that the peak value of the DC link voltage across the inverter bridge is different from the DC capacitor voltages $\left(V_{c 1}\right.$ and $\left.V_{c 2}\right)$. By substituting equation (6) into equation (4), the peak DC link voltage during the boost mode of operation can be calculated as follows:

$$
\hat{v}_{d c}=B \cdot V_{P V}=\frac{2 B}{B+1} V_{C}=V_{s} .
$$

The AC output voltage of a ZSI based PV-PCS can be controlled by varying the modulation index and the peak value of the AC output voltage can be expressed as:

$$
\hat{v}_{a c}=M \cdot B \cdot \frac{V_{P V}}{2}=M \frac{V_{P V}^{*}}{2}
$$

where $M$ is the modulation index.

Due to the presence of the blocking diode $(D)$, the input current to the Z-network is zero during the shoot-through state. The PV array has non-linear I-V and P-V characteristics as shown in Fig. 3. Depending on the temperature and irradiation, the output voltage and current of the PV array varies. A variety of MPPT algorithms have been reported to extract maximum power from a PV array [8]. The traditional MPPT control scheme for a ZSI based PV-PCS is shown in Fig. 4 (a). In the traditional control scheme for a ZSI based PVPCS, the shoot-through time period is directly calculated by the MPPT algorithm and accordingly two reference straight lines $\left(V_{P}\right.$ and $\left.V_{N}\right)$ are generated to produce shoot-through pulses with a simple boost control, as shown in Fig. 5. The Z-source capacitor voltage can be boosted according to the shoot-through time periods which are directly calculated by the MPPT algorithm. The input voltage of the Z-network is the output voltage of the PV array. In other words, the output voltage of the PV array can be controlled by controlling the Z-source capacitor or the DC link voltage. The Z-source capacitor voltage $\left(V_{c}\right)$ is improved so that it is equal to the MPP voltage of the PV panel $\left(V_{P V}^{*}\right)$. This is achieved by imposing the simultaneous conduction of each or any of the phase leg switches of the inverter bridge [13]. 


\section{UNIFIED MPPT CONTROL STRATEGY}

The traditional MPPT algorithm generates a shoot-through period $\left(T_{0}\right)$ to boost the Z-source capacitor voltage to the PV array voltage at the MPP. As discussed in the previous section, the shoot-through duty period $\left(T_{0}\right)$ required to boost the capacitor voltage is directly calculated and the shootthrough reference straight lines are generated. If the reference voltage of the capacitor is relatively higher than the PV voltage at the MPP, the capacitor voltage cannot be increased further since the shoot-through states are generated solely to track the voltage at the MPP. No capacitor voltage control beyond the PV array voltage at the MPP is facilitated in the traditional MPPT algorithms. Fig. 4 (b) shows the proposed unified control scheme which felicitates the MPPT as well as the capacitor voltage control. In the proposed MPP strategy, the net shoot-through period $T_{s h}$ is calculated by adding the shoot-through period $\left(T_{0}\right)$ required to boost the capacitor voltage to the MPP voltage with the additional shoot-through period required to control the capacitor voltage beyond the MPP voltage $\left(T^{\prime}{ }_{0}\right)$. Fig. 6 shows a flowchart of the proposed unified MPPT algorithm which tracks the MPP voltage and the reference Z-source capacitor voltage.

\section{A. MPPT algorithm}

The flow chart of the proposed unified MPPT algorithm, shown in Fig. 6, has two stages. The first stage tracks the MPP voltage of the PV panel and the second stage provides a further boost to the Z-source capacitor voltage, if needed. The first stage of the unified MPPT control strategy boosts the Z-source capacitor voltage so that it is equal to the MPP voltage of the PV array. To track the maximum power point voltage of the PV array, the MPPT algorithm is used to calculate the required shoot-through time period. By adjusting the shoot-through time interval, one can get the required amount of voltage across the DC link irrespective of the voltage supplied by the PV panel. Perturbation and Observation $(\mathrm{P} \& \mathrm{O})$ algorithm based MPPT is used in this paper to extract the MPP voltage of the PV panel in the first stage of the flowchart. In this method, the power is always measured and used as feedback to adjust the shoot-through duty cycle to reach the MPP. This is done by increasing/decreasing the shoot-through time period $\left(\mathrm{T}_{0}\right)$ with the shoot-through perturbation $\left(\Delta \mathrm{T}_{0}\right)$. Then the two reference straight lines $\mathrm{V}_{P}$ and $\mathrm{V}_{N}$, to generate shoot-through states, as shown in Fig. 5, are generated as follows:

$$
\begin{aligned}
& V_{P}=\left(1-\frac{T_{0}}{T}\right)=\left(1-D_{0}\right) \\
& V_{N}=-\left(1-\frac{T_{0}}{T}\right)=-V_{P} .
\end{aligned}
$$

These two straight lines $\left(\mathrm{V}_{P}\right.$ and $\left.\mathrm{V}_{N}\right)$ are compared with the high frequency carrier signal in order to generate shootthrough pulses. In simple boost control, the shoot-through frequency is twice the switching frequency since two shootthrough pulses are generated in one switching cycle. The capacitor voltage/DC link voltage can be improved until it reaches the MPP voltage of a PV array $\left(V_{P V}^{*}\right)$ and hence the maximum power from the PV array is extracted. Equation (6) can now be redefined as follows:

$$
v_{d c}=V_{C}=\frac{1-D_{0}}{1-2 D_{0}} V_{P V}=V_{P V}^{*} .
$$

As shown in the Fig. 6, the MPPT algorithm controls the capacitor voltage until it reaches $V_{P V}^{*}$, since the objective of the first stage is to generate the required shoot-through time $\left(\mathrm{T}_{0}\right)$ to maintain $\mathrm{V}_{C}$ to be equal to $V_{P V}^{*}$ as given in equation (6).

\section{B. Capacitor voltage control (CVC) algorithm}

To track the reference capacitor voltage $\left(V_{C}^{*}\right)$, the unified control algorithm generates an additional shoot-through factor $\left(\mathrm{T}_{0}{ }^{\prime}\right)$ which is the second stage of the flowchart shown in Fig. 6. For a particular solar irradiation and temperature level, the Z-source capacitor voltage is first set to the MPP voltage of the PV array with the MPPT algorithm. Then the actual capacitor voltage $\left(\mathrm{V}_{c}\right)$ is compared with the reference voltage $\left(V_{C}^{*}\right)$ which has to be maintained across the DC link of the inverter bridge. There is no additional shoot-through $\left(\mathrm{T}_{0}\right.$ ') period generated when the actual voltage across the Z-source capacitor is equal to the reference voltage. If the Z-source capacitor voltage needs to be increased substantially (ie. $V^{*}{ }_{C}>V_{C}$ ), an additional shoot-through period $\left(\mathrm{T}_{0}{ }^{\prime}\right)$ is generated and is added to the shoot-through period $\mathrm{T}_{0}$ generated in the MPPT algorithm. Similarly if the reference voltage is less than the MPP voltage of the PV panel (ie. $\mathrm{V}^{*}{ }_{C}<\mathrm{V}_{C}$ ), the net shootthrough period is calculated by subtracting an additional shootthrough period $\left(\mathrm{T}_{0}{ }_{0}\right)$ from the shoot-through time period $\left(\mathrm{T}_{0}\right)$ generated by the MPPT to provide a net shoot-through period $\left(\mathrm{T}_{s h}\right)$ to update the $\mathrm{Z}$-source capacitor voltage $\left(\mathrm{V}_{C}\right)$.

The new shoot-through time period $\left(\mathrm{T}_{s h}\right)$ has simultaneous control of the MPPT and the Z-source capacitor voltage and is defined as follows:

$$
\begin{gathered}
T_{s h}=T_{0} \pm T_{0}^{\prime} \\
D_{s h}=\frac{T_{s h}}{T}=\frac{T_{0}}{T} \pm \frac{T_{0}^{\prime}}{T}
\end{gathered}
$$

where $\mathrm{T}_{0}$ is used to track $V_{P V}^{*}$, and $\mathrm{T}_{0}$ ' is used to control the capacitor voltage according to the capacitor reference voltage $V_{C}^{*}$. The range of the new shoot-through time period $T_{s h}$, can be written as:

$$
\frac{T_{s h}}{T} \leq(1-M)
$$

From equations (12) and (14), the following is obtained:

$$
\pm \frac{T_{0}^{\prime}}{T} \leq 1-\left(M+\frac{T_{0}}{T}\right) .
$$

The maximum value of the additional shoot-through duty ratio for both the cases can be written as follows:

$$
\begin{array}{r}
\left(\frac{T_{0}^{\prime}}{T}\right)_{\text {max }} \leq 1-\left(M+\frac{T_{0}}{T}\right) \text { when } V_{C}^{*}>V_{C} \\
\left(\frac{T_{0}^{\prime}}{T}\right)_{\text {max }} \leq-\left(1-\left(M+\frac{T_{0}}{T}\right)\right) \text { when } V_{C}^{*}<V_{C} .
\end{array}
$$

The modulation index (M) and the MPPT shoot-through ratio $\left(D_{0}\right)$ limit the range of the additional shoot-through duty 


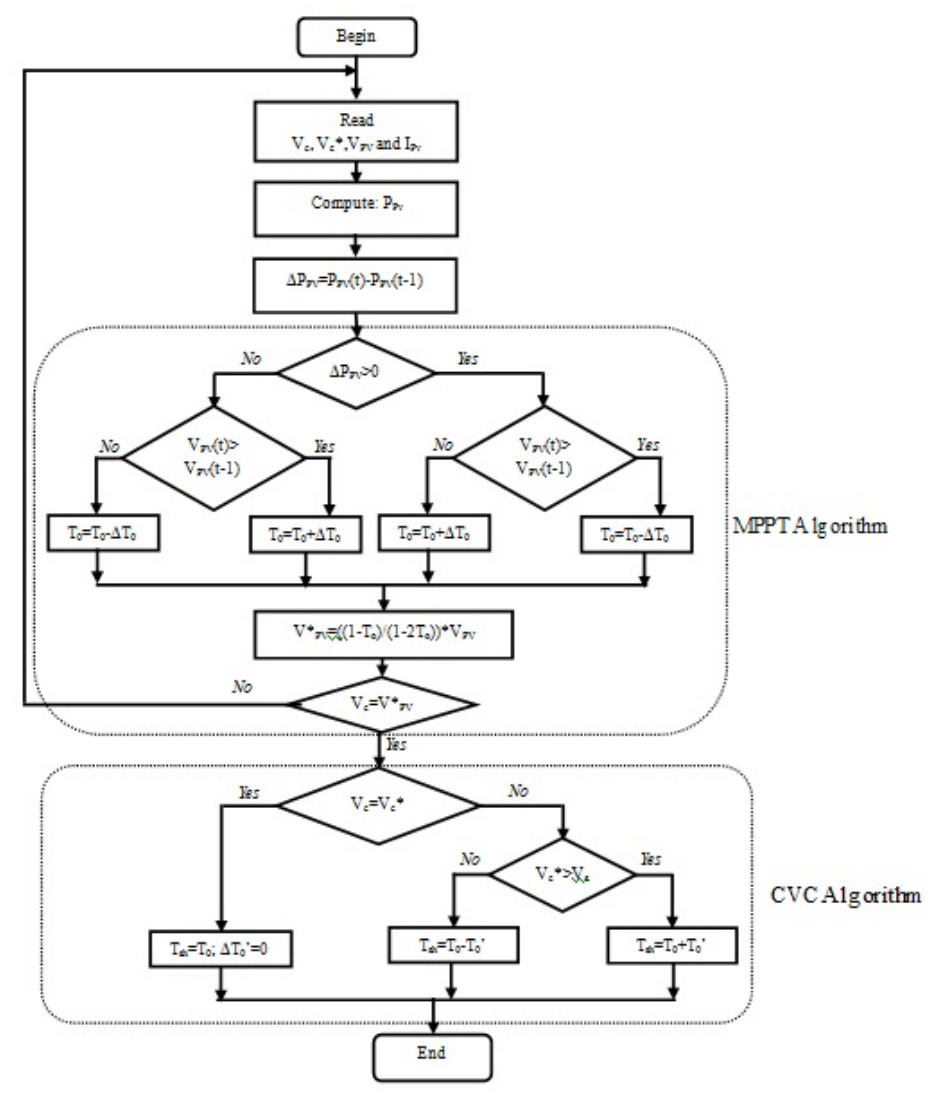

Fig. 6. Flowchart for unified capacitor voltage control.

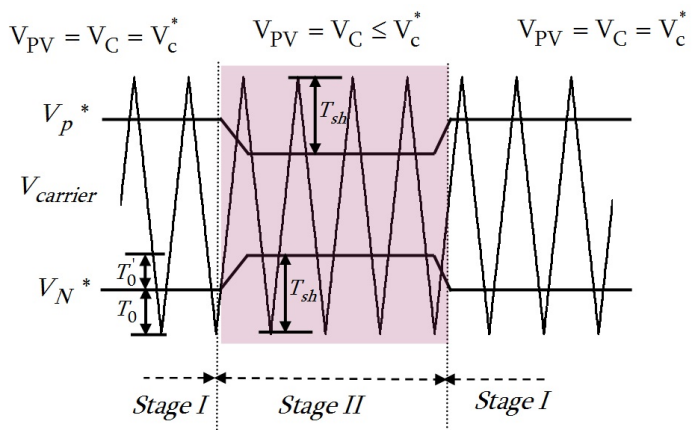

Fig. 7. Shoot-through generation by unified MPPT control strategy.

ratio $\left(\mathrm{D}_{0}{ }^{\prime}\right)$ and hence the capacitor voltage control. Since the value of $\mathrm{T}_{0}$ has to be very small to track the MPP voltage, the capacitor voltage boost factor $\left(\mathrm{B}_{C}\right)$ is controlled as a traditional ZSI.

The reference straight lines to generate the new shootthrough periods can now be equal to:

$$
\begin{aligned}
& V_{P}^{*}=\left(1-\frac{T_{s h}}{T}\right)=\left(1-D_{s h}\right) \\
& V_{N}^{*}=-\left(1-\frac{T_{s h}}{T}\right)=-V_{P}^{*}
\end{aligned}
$$

where $V_{P}^{*}$ and $V_{N}^{*}$ are the normalized values. Fig. 7 shows the generation of new shoot-through states $\left(\mathrm{T}_{s h}\right)$ with a simple boost control method. In the first stage, the capacitor voltage is boosted to the MPP voltage of the PV array $\left(V_{P V}^{*}\right)$. This is done by regulating the shoot-through state $\left(\mathrm{T}_{0}\right)$ by using the MPPT algorithm shown in Fig. 6 . When DC link voltage of the inverter needs to be increased beyond $V_{P V}^{*}$, a new shootthrough time period $\left(\mathrm{T}_{s h}\right)$ is generated by inserting an additional shoot-through time period $\left(\mathrm{T}_{0}\right.$ '). It should be noted that, the two straight lines $\left(V_{P}^{*}\right.$ and $\left.V_{N}^{*}\right)$ are continuously regulated to maintain the $\mathrm{Z}$-source capacitor voltage so that it is equal to the reference capacitor voltage $\left(V_{C}^{*}\right)$. The shoot-through period is adjusted according to the changes in the PV voltage at the MPP. In the unified MPPT, the minimum shoot-through period required to maintain the Z-source capacitor voltage as the PV voltage at the MPP is generated by the MPPT algorithm. In addition, the supplementary shoot-through period is generated by the CVC algorithm to provide an additional boost in the capacitor voltage to track the reference value.

By substituting (12) into (6) the average value of the Zsource capacitor and the DC link voltages are obtained as follows:

$V_{C}=\frac{T-\left(\frac{T_{0} \pm T_{0}^{\prime}}{T}\right)}{T-2\left(\frac{T_{0} \pm T_{0}^{\prime}}{T}\right)} V_{P V}^{*}=\frac{T-\left(\frac{T_{s h}}{T}\right)}{T-2\left(\frac{T_{s h}}{T}\right)} V_{P V}^{*}=\frac{1-D_{s h}}{1-2 D_{s h}} V_{P V}^{*}=v_{d c}$

The peak value of the AC output voltage of the ZSI can be defined as:

$$
\hat{v}_{a c}=M\left(\frac{1-D_{s h}}{1-2 D_{s h}}\right) \frac{V_{P V}^{*}}{2}=M \frac{v_{d c}}{2}
$$

The modulation index can be varied from zero to $V_{P}^{*}$. Shootthrough states are applied to all of the legs simultaneously. This can significantly reduce the current stress on the each 
TABLE I

PARAMETERS FOR SIMULATION

\begin{tabular}{|c|c|c|c|c|}
\hline & & Case I & Case II & Case III \\
\hline \multirow[t]{5}{*}{ PV array } & $\mathrm{V}_{O C}$ & $350 \mathrm{~V}$ & $350 \mathrm{~V}$ & $400 \mathrm{~V}$ \\
\hline & $\mathrm{I}_{S C}$ & $8.3 \mathrm{~A}$ & $9.6 \mathrm{~A}$ & $12.1 \mathrm{~A}$ \\
\hline & $\mathrm{V}_{P V^{*}}{ }^{2}$ & $\left(225^{\sim} 275\right) \mathrm{V}$ & $(200 \sim 250) \mathrm{V}$ & $(125 \sim 280) \mathrm{V}$ \\
\hline & $\mathrm{I}_{P V}{ }^{*}$ & $7.9 \mathrm{~A}$ & $9.4 \mathrm{~A}$ & $11.4 \mathrm{~A}$ \\
\hline & $\mathrm{P}_{P V}{ }^{*}$ & $2.9 \mathrm{~kW}$ & $3.36 \mathrm{~kW}$ & $4.84 \mathrm{~kW}$ \\
\hline $\begin{array}{c}\text { Reference } \\
\text { voltage }\end{array}$ & $\mathrm{V}_{C} *$ & $\mathrm{~V}_{P V}{ }^{*}$ & $275 \mathrm{~V}$ & $325 \mathrm{~V}$ \\
\hline \multirow[t]{2}{*}{ Z-network } & $\mathrm{L}_{1} \& \mathrm{~L}_{2}$ & \multicolumn{3}{|l|}{$1 \mathrm{mH}$} \\
\hline & $\mathrm{C}_{1} \& \mathrm{C}_{2}$ & \multicolumn{3}{|c|}{$1000 \mu \mathrm{F}$} \\
\hline $\begin{array}{c}\text { Load } \\
\text { parameters }\end{array}$ & RL & \multicolumn{3}{|c|}{$5 \mathrm{kVA}(0.9$ power factor $)$} \\
\hline $\begin{array}{l}\text { Switching } \\
\text { frequency }\end{array}$ & $f_{s}$ & \multicolumn{3}{|c|}{$5 \mathrm{kHz}$} \\
\hline
\end{tabular}
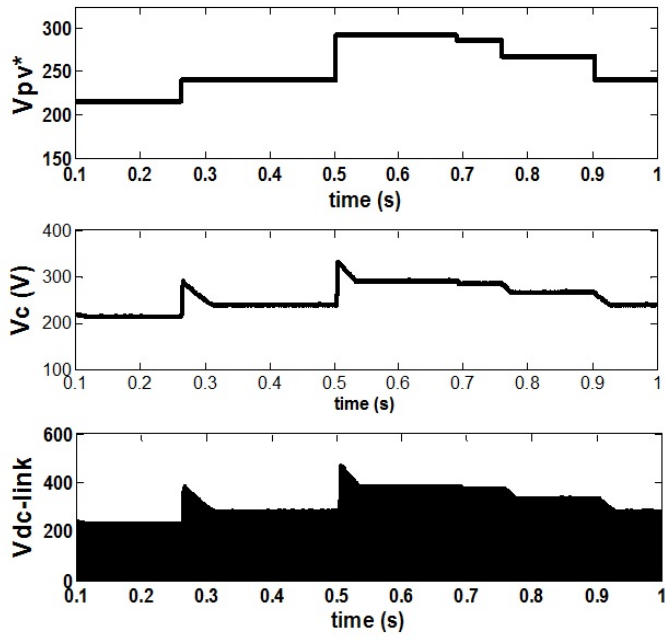

Fig. 8. Simulation results for case I.

switch during the shoot-through state [12]. Fig. 4 shows the PWM pulse generation for a ZSI using a simple boost control technique. It also shows the relationship between the reference sinusoidal and the reference shoot-through $\left(\mathrm{V}_{P}\right.$ and $\mathrm{V}_{N}$ ) signals and it also holds true for $\mathrm{V}_{P}{ }^{*}$ and $V_{N}^{*}$. The shootthrough periods should be diminished from the traditional zero periods without altering the active time periods to produce a less distorted AC output.

\section{RESULTS AND DISCUSSION}

The proposed MPPT control strategy is carried out for a ZSI based PV-PCS through Matlab/Simulink. A simple boost control is used to generate the required shoot-through periods with the proposed unified MPPT algorithm. The system parameters for the simulation are given in Table I. A PV array is modeled using the basic mathematical equations that take into consideration temperature and irradiation changes [34]. An LC filter is inserted between the inverter bridge and the three phase RL load to reduce the THD of the output parameters.

To verify the above mentioned features of the proposed MPPT control scheme, three cases are examined and simulated.

1. Case I $-V_{C}^{*}=V_{P V}^{*}$

2. Case II $-V_{P V}^{*}=(200 \sim 275) \mathrm{V} ; V_{C}^{*}=275 \mathrm{~V}$

3. Case III- $V_{P V}^{*}=\left(110^{\sim} 275\right) \mathrm{V} ; V_{C}^{*}=325 \mathrm{~V}$

Case I
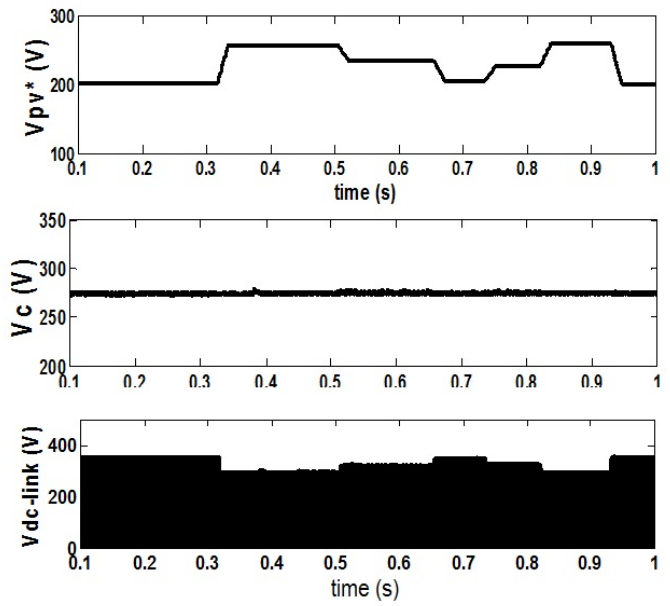

Fig. 9. Simulation results for case II.
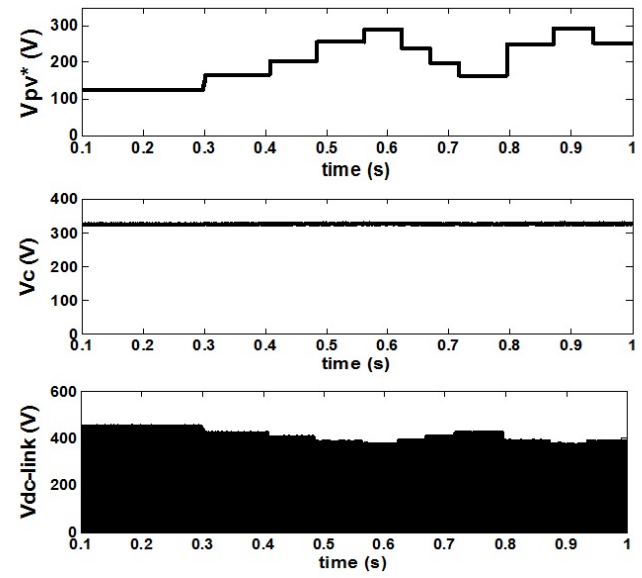

Fig. 10. Simulation results for case III.

The Z-source capacitor voltage is boosted in order to track the reference voltage generated by the MPPT algorithm given in Fig. 6. Since the additional shoot-through period is kept zero, no further boost in the capacitor voltage is allowed. Fig. 8 shows the simulation results of this case, where the capacitor voltage continuously tracks the MPP voltage of the PV panel. The range of the MPP voltage of the PV panel is considered to be (220-275) V depending on the different climate conditions. In this case only the shoot-through state $\left(T_{0}\right)$ is varied to regulate the capacitor voltage while the net shoot-through state is equal to $\mathrm{T}_{0}$. For example, at $800 \mathrm{~W} / \mathrm{m}^{2}$ and $50^{\circ} \mathrm{C}$, the voltage delivered by the PV panel $\left(\mathrm{V}_{P V}\right)$ is $200 \mathrm{~V}$ and the maximum power point voltage of the $\mathrm{PV}$ panel under these conditions is $220 \mathrm{~V}$. Now the shoot-through period is generated to provide a $20 \mathrm{~V}$ boost in the Z-source capacitors.

Now the required shoot-through $\left(\mathrm{T}_{0}\right)$ can be calculated by equation (10) as follows:

$$
220=\left(\frac{1-D_{0}}{1-2 D_{0}}\right) 200=B_{C} * 200
$$

where $\mathrm{B}_{C}$ is the capacitor voltage boost factor. Then:

$$
B_{C}=\frac{V_{P V}^{*}}{V_{P V}}=\frac{V_{C}^{*}}{V_{P V}}=\frac{220}{200}=1.1
$$



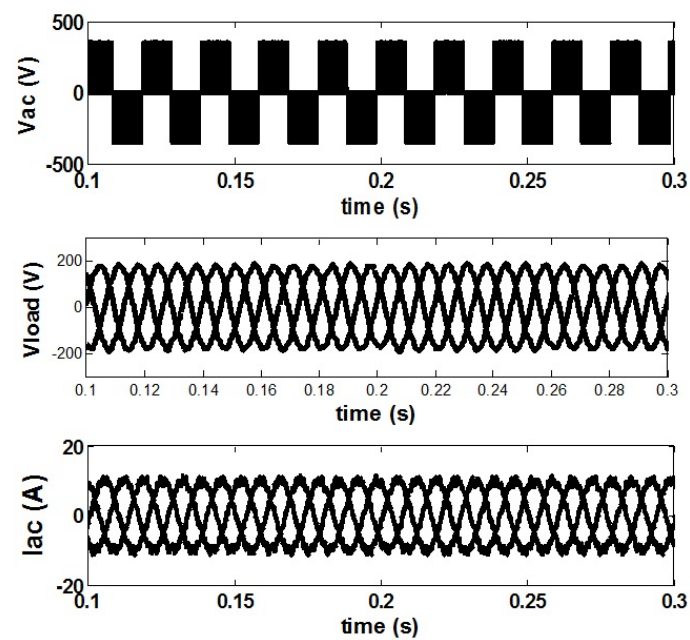

Fig. 11. Simulation results of output waveforms of proposed MPPT control.
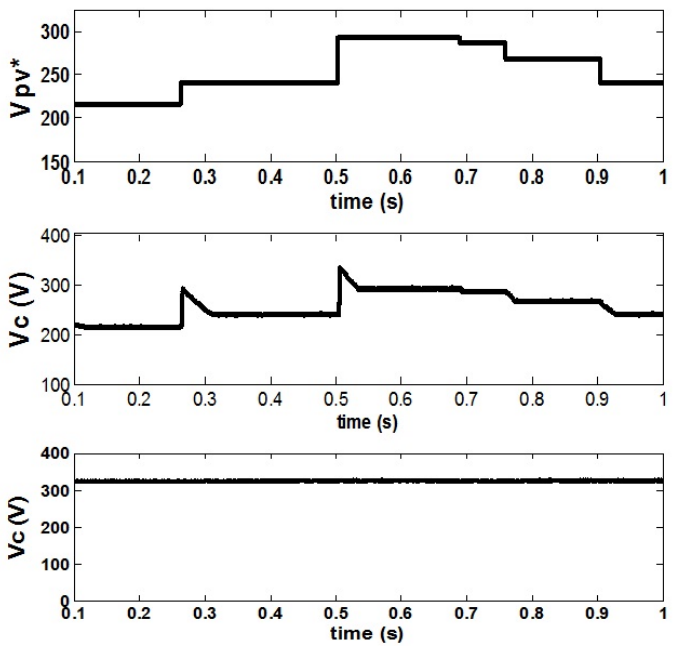

Fig. 12. Simulation results of traditional (middle) and proposed (lower) MPPT control for different temperature levels (upper) under same test conditions.

$$
\frac{T_{0}}{T}=\frac{B_{C}-1}{2 B_{C}-1}=0.0833
$$

The shoot-through period is varied for various climate conditions by adding/subtracting $\Delta \mathrm{T}_{0}$ and the capacitor reference voltage is boosted to extract the MPP voltage from the PV panel.

\section{Case II}

The Z-source capacitor voltage is boosted to a desired value beyond $V_{P V}^{*}$ as required in the DC link. Fig. 9 shows the results for this case for the wide range of variations in the $\mathrm{PV}$ voltage. For example, at $800 \mathrm{~W} / \mathrm{m}^{2}$ and $50^{\circ} \mathrm{C}$, the voltage delivered by the PV panel $\left(\mathrm{V}_{P V}\right)$ is $180 \mathrm{~V}$. The voltage of the PV panel at the MPP is $200 \mathrm{~V}$. $275 \mathrm{~V}$ is the voltage that has to be maintained across the Z-source capacitor throughout operation irrespective of climate changes. As detailed in the previous case, the shootthrough time period needed to boost the capacitor voltage to the MPP voltage of the PV panel is calculated as 0.09 . Now the additional shoot-through period, $\left(\mathrm{T}_{0}{ }^{\prime}\right)$, required for boosting the capacitor voltage further to $275 \mathrm{~V}$ can be calculated by the following method.

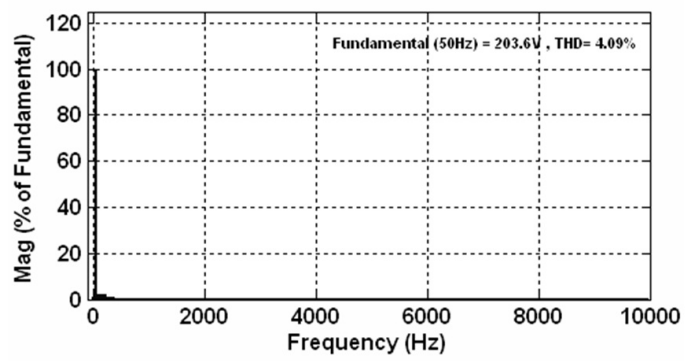

(a)

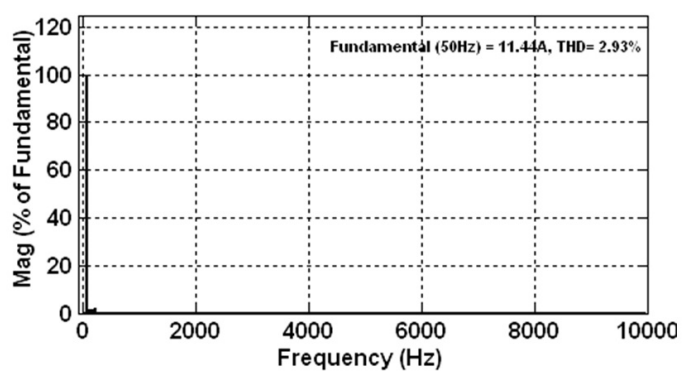

(b)

Fig. 13. THD of output parameters using proposed method Output voltage. (b) Output current.

The additional capacitor boost factor is:

$$
B_{C}^{\prime}=\frac{V_{C}^{*}}{V_{P V}^{*}}=\frac{275}{200}=1.375
$$

Then the shoot-through time period is:

$$
\frac{T_{0}^{\prime}}{T}=\frac{B_{C}^{\prime}-1}{2 B_{C}^{\prime}-1}=0.21
$$

Then the new shoot-through period to be inserted into all the switching waveforms can be calculated as:

$$
\frac{T_{s h}}{T}=\frac{T_{0}+T_{0}^{\prime}}{T}=0.09+0.21=0.3
$$

The maximum value of the modulation index to control the AC output voltage is limited to 0.7 .

Case III

Similar to case II, $325 \mathrm{~V}$ is maintained across the Z-source capacitor for the PV output voltages in the range of (100300) $\mathrm{V}$ for different climate conditions. The simulation results for these conditions are shown in Fig. 10. As can be seen, even though there are a lot of variations in the MPP voltage of the PV array, the voltage across the Z-source capacitor is constantly maintained as the preset value. This is due to the additional shoot-through period $\left(\mathrm{T}_{0}\right.$ ') generation by the proposed control method. The same response is obtained when the reference voltage of the capacitor is increased to different values.

Fig. 11 shows the $\mathrm{AC}$ waveforms of the inverter such as the output voltage before the filter, the output voltage after the filter and the output current after the filter, respectively, for the cases considered in Fig. 10. The voltage across the Z-source capacitor with the traditional algorithm and the proposed algorithm, to maintain $\mathrm{V}_{c}=325 \mathrm{~V}$, is shown in Fig. 12 for different temperature levels under the same test conditions. It can be seen that in the traditional method, the Z-source 


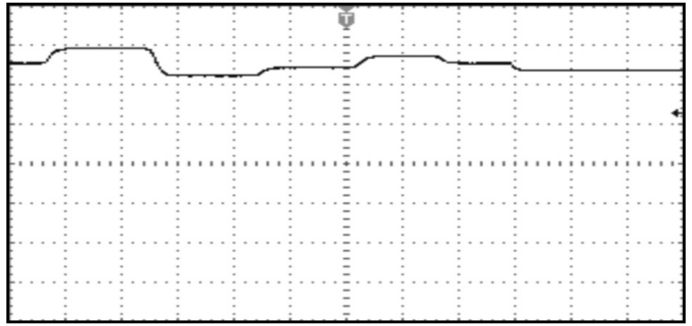

(a)

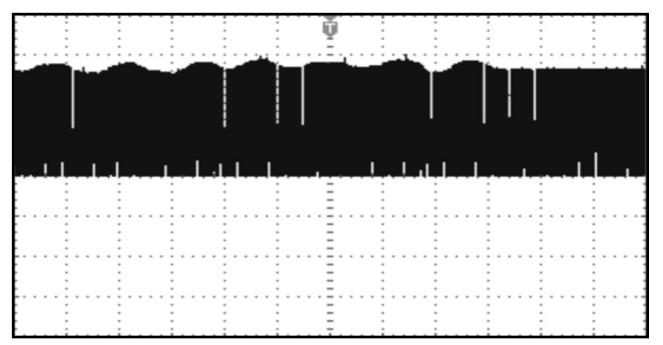

(b)

Fig. 14. Experimental results of the traditional MPPT algorithm for case I (a) Capacitor voltage. (b) DC link voltage. $\mathrm{x}$-axis $=$ time (s), Y-axis voltage (V)

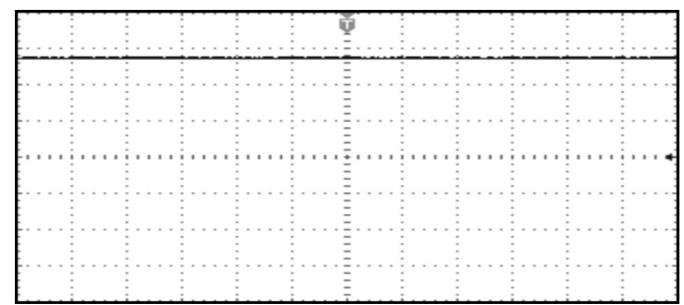

(a)

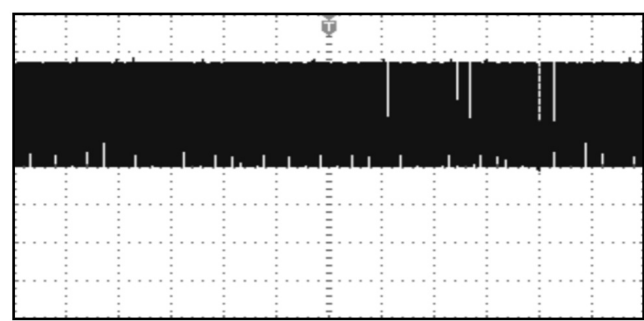

(b)

Fig. 15. Experimental results of the unified MPPT algorithm for case II. (a) Capacitor voltage. (b) DC link voltage. $\mathrm{x}$-axis $=$ time $(\mathrm{s})$, Y-axis voltage (V)

capacitor voltage is varied based on the MPP voltage of the PV cell. However, in the proposed method the Z-source capacitor voltage is constantly maintained at the reference value (ie. $325 \mathrm{~V})$. The harmonic profile of the output voltage/current waveforms of the proposed system is shown in Fig. 13 and it confirms an improvement in the THD. In the traditional system the $\mathrm{THD}_{v}$ and the $\mathrm{THD}_{i}$ are found to be $6.21 \%$ and $4.32 \%$, respectively.

The proposed unified MPPT control strategy is implemented with a digital signal processor (DSP). The Z-source capacitor voltage and the DC link current are sensed by isolation devices, amplifiers, and a 12-bit analog-to digital converter within the DSP. The PWM pulses with inserted shoot-through states are generated by the DSP and then sent out through

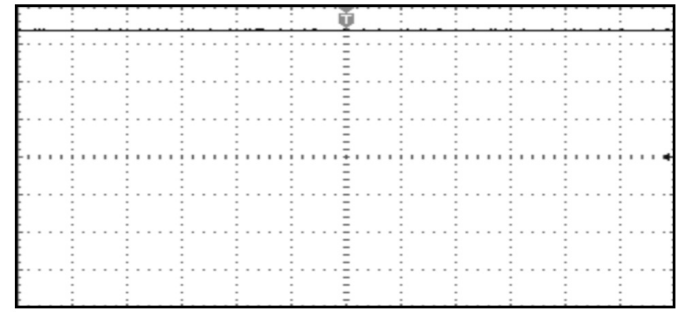

(a)

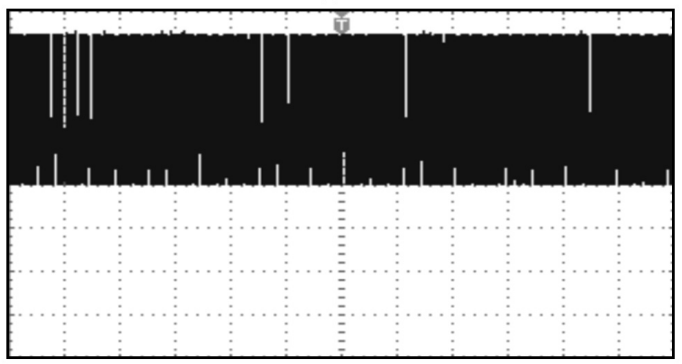

(b)

Fig. 16. Experimental results of the unified MPPT algorithm for case III. (a) Capacitor voltage. (b) DC link voltage. $\mathrm{x}$-axis = time $(\mathrm{s})$, Y-axis voltage $(\mathrm{V})$

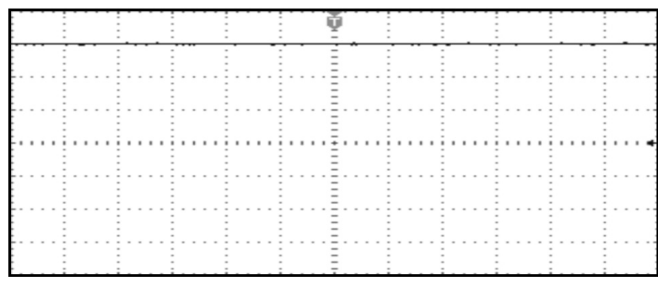

(a)

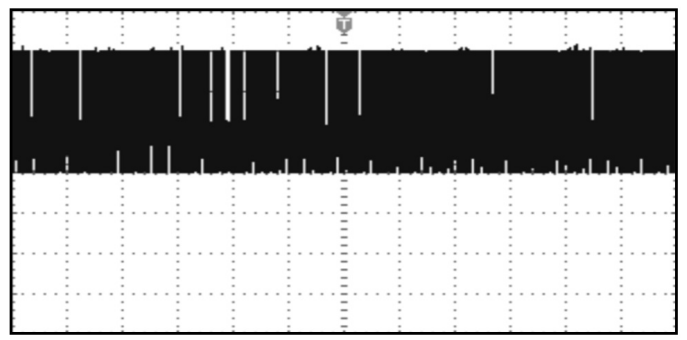

(b)

Fig. 17. Experimental results of the unified MPPT algorithm to maintain $\mathrm{V}_{C}=300 \mathrm{~V}$ (a) Capacitor voltage (b) DC link voltage. $\mathrm{x}$-axis $=$ time (s), Yaxis voltage $(\mathrm{V})$

six independent PWM channels to gate the six switches (IGBT modules) of the implemented inverter. The hardware reference signals and the high frequency triangular signal were generated by the DSP and then compared to generate the switching pulses to the inverter. The experimental results for the proposed unified MPPT algorithm for a ZSI based PVPCS for the various cases discussed in this paper are shown in Fig. 14-17. To improve the DC link voltage beyond $V_{P V}^{*}$, the proposed unified MPPT control algorithm generates an additional shoot-through interval to the inverter bridge.

\section{Conclusions}

This paper presented a unified MPPT control strategy for ZSI based PV-PCSs. The proposed scheme realizes both the 
tracking of the MPP voltage of the solar panel and the regulation of the capacitor voltage to the reference value simultaneously. Three different cases at different irradiation and temperature levels were considered to investigate the suitability of the proposed system using the Matlab/Simulink package. The effectiveness of the proposed algorithm was verified by an experiment in the laboratory and the experimental results agree with the simulated results. The output AC waveforms still hold the optimum THD profile and are free from low frequency distortions.

\section{REFERENCES}

[1] B. K. Bose, P. M. Szezesny, and R. L. Steigerwald, "Microcontroller control of residential photovoltaic power conditioning system," IEEE Trans. Ind. Applicat., Vol. 21, No. 5, pp. 1182-1191, Sep. 1985.

[2] D. Saha and V. P. Sundarsingh, "Novel grid-connected photovoltaic inverter," Proc. Inst. Elect. Eng., Vol. 143, No. 2, pp. 143-56, 1996.

[3] B. M. T. Ho and H. S. H. Chung, "An integrated inverter with maximum power tracking for grid-connected pv systems," IEEE Trans. Power Electron., Vol. 20, No. 4, pp. 953-962, Jul. 2005.

[4] Y. Chen and K. M. Smedley, "A cost-effective single-stage inverter with maximum power point tracking," IEEE Trans. Power Electron., Vol. 19, No. 5, pp. 1289-1294, Sep. 2004.

[5] S. Jain and V. Agarwal, "A single stage grid connected inverter topology for solar PV systems with maximum power point tracking," IEEE Trans. Power Electron., Vol. 22, No. 5, pp. 1928-1940, Sep. 2007.

[6] S. B. Kjaer, J. K. Pedersen, and F. Blaabjerg, "A review of single-phase grid-connected inverters for photovoltaic Modules," IEEE Trans. Ind. Appl., Vol. 41, No. 5, pp. 1292-1306, Sep./Oct. 2005.

[7] N. Kasa, T. Iida, and H. Iwamoto, "Maximum power point tracking with capacitor identifier for photovoltaic power system," Proc. Inst. Elect. Eng., Vol. 147, No. 6, pp. 497-502, Nov. 2000.

[8] V. Salas, E. Olias, A. Barrado, and A. Lazaro, "Review of the maximum power point tracking algorithms for stand-alone photovoltaic systems," Solar Energy Materials \& Solar Cells, Vol. 90, pp. 1555-1578, Jul. 2006.

[9] F. Z. Peng, "Z-source inverter," IEEE Trans. Ind. Applicat., Vol. 39, No. 2, pp. 504-510, Mar./Apr. 2003.

[10] F. Z. Peng, M. Shen, and Z. Qian, "Maximum boost control of the Z-source inverter," IEEE Trans. Power Electron., Vol. 20, No. 4, pp. 833-838, 2005.

[11] M. Shen, A. Joseph, J. Wang, F. Z. Peng, and D. J. Adams, "Comparison of traditional inverters and Z-source inverter for fuel cell vehicles," IEEE Trans. Power Electron., Vol. 22, No. 4, pp. 1453-1463, Jul. 2007.

[12] S. Thangaprakash and A. Krishnan, "Implementation and critical investigation on modulation schemes of three phase impedance source inverters," Iranian. J. Electric. Electron. Eng., Vol. 6, No. 2, pp. 84-92, 2010.

[13] S. Thangaprakash, A. Krishnan, P. Jothibasu, and C. S. Subashkumar, "Analysis of advanced pulse width modulation schemes of Z-source inverter," Aust. J. Elect. Electron. Eng., Vol. 8, No. 2, pp. 155-170, 2011.

[14] F. Z. Peng, X. Yuvan, X. Fang, and Z. Qian, "Z-source inverter for motor drives", IEEE Trans. Power Electron., Vol. 20, No. 4, pp. 857-863, Jul. 2005.

[15] S. Thangaprakash and A. Krishnan, "Performance improvement of Zsource inverter fed induction motor drives using modified voltage space vector," Aust. J. Electric. Electron. Eng., Vol. 7, No. 2, pp. 163-174, 2010.

[16] S. Thangaprakash and A. Krishnan, "Current mode integrated control technique for Z-source inverter fed induction motor drives," Journal of Power Electronics, Vol. 10, No. 3, pp. 285-292, May 2010.

[17] Huang, Y., Shen, M., Peng, F. Z. and Wang, J., "Z-source inverter for residential photovoltaic systems", IEEE Trans. Power Electron., Vol. 21, No. 6, pp. 1776-1782, Nov. 2006.

[18] C. J. Gajanayake, D. M. Vilathgamuwa, and P. C. Loh, "Development of a comprehensive model and a multi-loop controller for Z-source inverter DG system," IEEE Trans. Ind. Electron., Vol. 54, No. 4, pp. 2352-2359, Aug. 2007
[19] J. W. Jung and A. Keyhani, "Control of a fuel cell based Z-source Converter," IEEE Trans. Energy Convers., Vol. 22, No. 2, pp. 467-476, Jun. 2007.

[20] F. Z. Peng, M. Shen, and A. Joseph, "Z-source inverters, controls, and motor drive applications," KIEE Int. Trans. Elect. Mach. and Energy Convers. Sys., Vol. 5-B, pp. 6-12, 2005.

[21] F. Z. Peng, M. Shen, and K. Holland, "Application of Z-source inverter for traction drive of fuel cell-battery hybrid electric vehicles," IEEE Trans. Power Electron., Vol. 22, No. 3, pp. 1054-1061, May 2007.

[22] F. Z. Peng, X. Yuan, X. Fang, and Z. Qian, "Z-source inverter for adjustable speed drives," IEEE Power Electron. Letters, Vol. 1, No. 2, pp. 33-35, 2003.

[23] L. Sack, B. Piepenbreier, and M. V. Zimmermann, "Dimensioning of the Z-source inverter for general purpose drives with three-phase standard motors," in Proc. IEEE-PESC, pp. 615-620, 2008.

[24] Z. Chen, X. Zhang, and J. Pan, "An integrated inverter for a singlephase single-stage grid-connected PV system based on Z-source," Bull. Pol. Ac.: Tech., Vol. 55, No. 3, pp. 263-272, 2007.

[25] S. Thangaprakash and A. Krishnan, "Integrated control algorithm for an effective control of Z-source inverter using modified voltage space vector," Aust. J. Electric. Electron. Eng., Vol. 7, No. 1, pp. 53-64, 2010.

[26] P. C. Loh, D. M. Vilathgamuwa, Y. S. Lai, G. T. Chua, and Y. W. $\mathrm{Li}$, "Pulse width modulation of Z-source inverters," IEEE Trans. Power Electron., Vol. 20, No. 6, pp. 1346-1355, Nov. 2005.

[27] Y. Tang, S. Xie, C. Zhang, and Z. Xu, "Improved Z-source inverter with reduced Z-source capacitor voltage stress and soft-start capability," IEEE Trans. Power Electron., Vol. 24, No. 2, pp. 409-415, Feb. 2009.

[28] Q. V. Tran, T. W. Chun, J. R. Ahn, and H. H. Lee, "Algorithms for controlling both the dc boost and ac output voltage of Z-source inverter," IEEE Trans. Ind. Electron., Vol. 54, No. 5, pp. 2745-2750, Oct. 2007.

[29] Q. V. Tran, T. W. Chun, H. G. Kim, and E. C. Nho, "Minimization of voltage stress across switching devices in the Z-source inverter by capacitor voltage control," Journal of Power Electronics, Vol. 9, No. 3, pp. 335-342, May 2009.

[30] S. Yang, X. Ding, F. Z. Peng, and F. Z. Z. Qian, "Unified control technique for Z-source inverter," in Proc. IEEE-PESC, pp. 3236-3242, 2008.

[31] P. Xu, C. Zhang, R. Cao, and L. Zhang, "Study of Z-source inverter for grid connected PV system," in Proc. PESC-2006, pp. 1-8, 2006.

[32] H. S. Bae, J. H. Park, G. H. Cho, and G. J. Yu, "New MPPT control strategy for two-stage grid-connected photovoltaic power conditioning system," Journal of Power Electronics, Vol. 7, No. 2, pp. 174-180, Apr. 2007.

[33] J. H. Park, H. G. Kim, E. C. Nho, and T. W. Chun, "Power conditioning system for a grid connected $\mathrm{PV}$ power generation using a quasi Z-source inverter," Journal of Power Electronics, Vol. 10, No. 1, pp. 79-84, Jan. 2010.

[34] I. H. Altas and A. H. Sharaf, "A photovoltaic array simulation model for matlab/Simulink GUI environment" in Proc. ICCEP-2007, pp. 341-345, 2007.

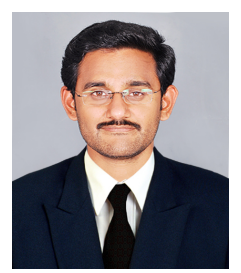

Sengodan Thangaprakash received his B.E. in Electrical and Electronics Engineering and his M.E. in Power Electronics and Drives from Bharathiar University and Anna University Chennai, Tamilnadu, India, in 2002 and 2004, respectively. He then received his Ph.D. in Electrical Engineering from Anna University Chennai, India, in 2011. From 2004 to mid-2011, he was working with the KSR College of Engineering and the Sri Shakthi Institute of Engineering and Technology, Tamilnadu, India. Currently he is working as a Senior Lecturer in the School of Electrical Systems Engineering, University Malaysia Perlis (UniMAP), Malaysia. His current research interests include power electronics circuits, renewable power conversion systems and solid state control of electrical drives. He has authored more than twenty papers in international journals and conferences. Dr. Thangaprakash is a member of IEEE, IEEE-Power Electronics Society, IEEE-Communications Society and a life member of the Indian Society for Technical Education (ISTE). He is an editorial board member for the International Journal of Engineering, Science and Technology, Nigeria and a reviewer for the International Journal of Automation and Computing (Springer) and various IEEE international/national conferences. 